\title{
Образование рабочих машиностроительных предприятий в годы первых пятилеток: структура, проблемы и методы их решения
}

\begin{abstract}
Аннотахия: статья посвящена проблемам образования рабочих советских машиностроительнъх предприятий в годы первых пятилеток как одному из важнейтих элементов соииально-кулвпрной системы советского общества. В исследовании рассматривается историография данной проблемъ, а также фактическая законодательная база, определившая основнъе тендениии и направления развития образования советского индутриального общества. Первостепенное внимание уделяется вопросам профессионального образования, которое полностью входило в компетенцию самих предприятий. Вопросы общего образования затрагиваются лишь частично (в том случае, если курсъ или занятия проводились непосредственно заводом). Анализ основных проблем, связанньх с образованием рабочих, позволяет проследить связь между общегосударственньми прочессами, зафиксированными нормативными актами, и их реализачией в рамках конкретных предприятий.
\end{abstract}

Ключевые слова: история, индустриализачия, машиностроение, образование, квалификачия, фабрично-заводские училища, ликвидачия неграмотности, техникумы, учебные курсы, профессия.

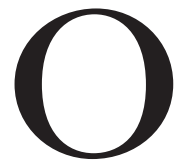

бразование на предприятиях советской промышленности в годы первых пятилеток являлось одним из важнейших факторов индустриального развития государства и, вместе с тем, представляло собой широкий культурный феномен, характеризующий социальную сферу жизни общества. Система курсов, школ, фабрично-заводских училищ способствовала как решению производственных задач (прежде всего, поднимая квалификацию работников), так и расширению культурных горизонтов и интересов трудящихся.

Реализация программы по ликвидации неграмотности в 1920-30-е гг. стала одним из наиболее значимых культурно-просветительских событий первых десятилетий существования СССР. Однако масштабность процесса предполагала достаточно широкие временные рамки. Так, в Постановлении ВЦИК СНК РСФСР от 31 августа 1925 г. «О введении в РСФСР всеобщего начального обучения и построения школьной сети» говорилось, что «Предельным сроком для введения всеобщего обязательного обучения на всей территории Р.С.Ф.С.Р. считать 1933/1934 учебный год. В первую очередь всеобщее обучение должно быть проведено в тех областях и губерниях, где это окажется возможным по состоянию местного бюджета и школьной сети, а также плотности населения. Принять меры к тому, чтобы к десяти- летию Октябрьской Революции была обеспечена общедоступность школ первой ступени, при условии добровольного посещения ее, а в следующие годы было осуществлено всеобщее начальное обучение» ${ }^{1}$. В постановлении 1925 г. также регламентировались вопросы, связанные с конкретными организационными мероприятиями; речь, в частности, шла о функционировании трудовых школ первой ступени (для детей от восьми до одиннадцати лет), второй ступени и семилеток. Отдельное внимание уделялось и формированию педагогического состава. Так, в частности, отмечалось, что «учащиеся в педагогических техникумах и курсах обеспечиваются стипендиями в пределах, отпускаемых Народному Комиссариату Просвещения по бюджету сумм, причем учащиеся обязываются за стипендию службой в трудовых школах первой ступени: оканчивающие педагогические техникумы - в течение пяти лет, оканчивающие краткосрочные педагогические курсы - в течение трех лет» ${ }^{2}$. Таким образом, к началу первых пятилеток основной план образовательных преобразований был готов, и оставалась самая трудная задача - его реализация.

\footnotetext{
${ }^{1}$ Постановление ВЦИК СНК РСФСР от 31 августа 1925 г. «О введении в РСФСР всеобщего начального обучения и построения школьной сети». URL: http://www.libussr.ru/doc_ ussr/ussr_2624.htm (дата обращения 19.09.12).

${ }^{2}$ Там же.
} 


\section{Исторический журнал: научные исследования № 3 (15) • 2013}

Советская историография достаточно большое внимание уделяла как проблемам системы образования в целом, так и частным вопросам, связанным с работой в среде национальных меньшинств, формированием педагогического состава, организацией различных курсов и движений по ликвидации неграмотности, а также методикам обучения и грамотному использованию в них понятных и актуальных политических лозунгов ${ }^{3}$.

Советские авторы обращали внимание на проблемы образовательных преобразований, прежде всего, их затянутость и невыполнение в сроки. Так, В.С. Лельчук отмечал, что «ликвидация безграмотности затянулась и не была преодолена в предполагавшиеся сроки. Нехватка средств замедляла введение всеобщего начального обучения, а подлинными центрами культуры стали новостройки, первенцы социалистической индустриализации» ${ }^{4}$. Далее Лельчук обращает внимание на то, что «на первый план выдвинулись вопросы квалификации. Средняя продолжительность обучения рабочих в 1932-33 гг. составляла 3,5 года (в машиностроении - около 4 лет). При этом объём знаний у молодых рабочих, поступавших из ФЗУ на производство, был невелик» ${ }^{5}$. Резюмируя образовательные достижения советской власти, Лельчук отмечал, что в 1937 г. на 11 рабочих приходился всего лишь один, имеющий высшее или среднее специальное образование ${ }^{6}$.

Тем не менее, ключевая задача в области образования (а именно, ликвидация неграмотности) к концу второй пятилетки была, по большей части, решена. В середине 1930-х гг. было признано, что основная цель общегосударственного масштаба достигнута. Ликвидация неграмотности возлагалась теперь на соответствующие секции при местных Советах. Одновременно пересматривались программы школ ликбеза, рассчитанные на 330 учебных занятий (10 месяцев в городе и 7 месяцев на селе). Актуальной задачей считалась теперь борьба с малограмотностью, ставшей заметным тормозом

\footnotetext{
${ }^{3}$ См. Российская педагогическая энциклопедия в двух томах. T.1. M. 1993. URL: http://museum.edu.ru/catalog.asp?cat_ob_ no=13047\&ob_no=13401 (дата обращения: 19.09.12); Фрид Л.С. Очерки по истории развития политико-просветительной работы в РСФСР (1917-1929). Л. 1941; Богданов И.М. Грамотность и образование в дореволюционной России и в СССР. М. 1964; Куманев В.А. Революция и просвещение масс. М. 1973; Штамм С.И. Управление народным образованием в СССР. (1917-1936). М. 1985.

4 Лельчук В.С. Индустриализация СССР: история, опыт, проблемы. М. 1984. С. 203

${ }^{5}$ Там же. С. 204, 205, 209.

${ }^{6}$ Там же. С. 212.
}

в организации и расширении индустриального производства ${ }^{7}$.

Значительное внимание в годы первых пятилеток уделялось и развитию среднего технического, а также высшего образования. Ключевым моментом в этом процессе стало принятие постановления ЦИК и СНК СССР от 23 июля 1930 г. «О реорганизации вузов, техникумов и рабфаков», в котором говорилось, что «бурные темпы социалистического переустройства страны с исключительной остротой выдвинули неотложную задачу подготовки новых пролетарских кадров специалистов, в первую очередь руководителей и организаторов народного хозяйства СССР». Отмечалось, что «разрешение этой задачи невозможно без коренной реорганизации существующих вузов, техникумов и рабфаков на основе решительного сближения теоретического обучения и производственной практики, специализации учебных заведений по отраслевому признаку и приведения самой системы образования в соответствие с экономическим районированием страны, хозяйственным и культурным строительством национальных районов и с организацией промышленности, сельского хозяйства, торговли, транспорта и т.д.». Таким образом, была проведена реорганизация большинства факультетов, а также при каждом вузе были созданы рабфаки ${ }^{8}$.

Важным элементом функционирования системы среднего технического и высшего образования были стипендии. Так, согласно постановлению СНК СССР от 10 февраля 1933 г. № 181 «О порядке стипендиального обеспечения учащихся вузов, втузов, техникумов и рабфаков» устанавливались размеры стипендий отдельно для учащихся с нормальной или высокой успеваемостью. И, если на рабфаках разрыв был минимален: отличники, независимо от курса получали 55 руб. в месяц против 45 руб. у обычных учащихся, то в вузах ситуация была кардинально иной. Размер стипендии различался, как в зависимости от курса, так и от успеваемости; причём максимальный разрыв превышал 2 раза. Так, если обычный студент первого курса получал, например, 55 руб., то отличник пятого курса уже 135 руб. Похожая ситуация была и в техникумах ${ }^{9}$.

\footnotetext{
${ }^{7}$ См. Российская педагогическая энциклопедия в двух томах. T.1. M. 1993 URL: http://museum.edu.ru/catalog.asp?cat_ob_ no=13047\&ob_no=13401 (дата обращения: 19.09.12).

${ }^{8}$ Постановление ЦИК и СНК СССР от 23 июля 1930 г. «О реорганизации вузов, техникумов и рабфаков». URL: http://www. libussr.ru/doc_ussr/ussr_3657.htm (дата обращения 23.09.12).

${ }^{9}$ Постановление СНК СССР от 10 февраля 1933 г. № 181 «О порядке стипендиального обеспечения учащихся вузов, втузов, техникумов и рабфаков». URL: http://www.libussr.ru/doc_ussr / ussr_3860.htm (дата обращения 23.09.12).
} 
При этом, однако, следует учесть, что стипендиями обеспечивались не все учащиеся. Так, ещё в постановлении ЦИК СССР № 11 и СНК СССР № 504 от 13 июля 1931 г. «О порядке обеспечения стипендиями учащихся рабочих факультетов» отмечалось, что «на дневных рабочих факультетах при педагогических, медицинских и экономических высших учебных заведениях, а также на национальных рабочих факультетах стипендиями обеспечиваются учащиеся всех курсов» ${ }^{10}$. Что касается дневных рабочих факультетов при всех прочих учебных заведениях, то здесь стипендиями обеспечивались только учащиеся II и III курсов. На I же курсе этих факультетов стипендиями обеспечивались только отдельные группы учащихся, которые в силу отсутствия необходимой квалификации или по другим причинам не могли быть целесообразно использованы на работе. При этом, количество учащихся I курса, которые обеспечивались стипендиями, не должно было превышать 25\% от общего количества учащихся I курса. На вечерних рабочих факультетах стипендии назначались только учащимся последнего курса ${ }^{11}$.

Таким образом, к 1936 г. было обучено около 40 млн. неграмотных. В 1933-1937 гг. только в учтенных школах ликбеза занимались свыше 20 млн. неграмотных и около 20 млн. малограмотных. К концу 1930-х гг. неграмотность утратила характер острой социальной проблемы. По данным переписи 1939 г., грамотность лиц в возрасте от 16 до 50 лет приблизилась к 90\%, а к началу 1940-х гг. задача по ликвидации неграмотности была, в основном, решена ${ }^{12}$.

В современных исследованиях образование, как правило, рассматривается в широком социально-экономическом контексте. Особый интерес представляет вопрос об эффективности образования. Активно исследуется теория человеческого капитала, оценка дохода от профессионального опыта. При этом изучение воздействия образовательного потенциала на экономический рост осуществляется с использованием методов математической статистики. В частности, Миронов Б.Н. считает, что экономическая отдача от образовательных программ периода первых пятилеток дала әффект лишь спустя 20-25 лет ${ }^{13}$.

\footnotetext{
10 Постановление ЦИК СССР № 11 и СНК СССР № 504 от 13 июля 1931 г. «0 порядке обеспечения стипендиями учащихся рабочих факультетов». URL: http://www.libussr.ru/doc_ ussr/ussr_3747.htm (дата обращения: 23.09.12).

11 Там же.

12 См. Российская педагогическая энциклопедия в двух томах. T.1. M. 1993 URL: http://museum.edu.ru/catalog.asp?cat_ob_ no=13047\&ob_no=13401 (дата обращения: 19.09.12).

${ }^{13}$ См. Миронов. Б.Н. Экономический рост и образование в России и СССР в 19-20 веках // Отечественная история. 1994. № 4-5. С. 111-125.
}

В постсоветской историографии существуют и другие направления исследований по данной тематике. Изучая такие показатели как количество человек, проходивших обучение в конкретный момент времени, а также динамику показателя среднего количества лет обучения, исследователи отмечают такие явления как массовое обучение взрослого населения, сопровождавшееся существенным увеличением государственных расходов на образование; сокращение гендерного диспаритета в образовательном уровне населения. Делаются выводы о достаточно высокой әффективности системы образования, но отмечается, что полученный от этого экономический импульс, напротив, стал ослабевать в 1970-80-е гг. ${ }^{14}$.

Отдельным направлением исследований являются работы, посвящённые социальной истории конкретных крупных предприятий, таких как Московский электромеханический завод, завод «Серп и молот» и др., в которых уделяется определённое внимание, в том числе, и вопросам организации образования на рассматриваемых предприятиях ${ }^{15}$.

В ряде постсоветских исследований была также осуществлена попытка путём публикации источников личного происхождения (писем, откликов и т.п.) взглянуть на вопросы образования глазами рядовых рабочих, ощущавших на себе все трудности и достижения первых пятилеток. ${ }^{16}$

Таким образом, историография акцентировала своё внимание, прежде всего, на изучении общих принципов образовательной реформы на государственном уровне, анализе основных общесоюзных достижений и т. п., либо же опиралась на изучение реальных жизненных ситуаций отдельных рабочих; при этом, структура образовательной системы и основные механизмы её функционирования, а также связанные с этим сложности и проблемы на отдельных предприятиях оставались в тени.

В данной работе проводится анализ системы образования рабочих на предприятиях в годы ин-

\footnotetext{
${ }^{14}$ См. Диденко Д.В. Социально-экономические аспекты модернизации советской образовательной системы в условиях догоняющего развития // Мобилизационная модель экономики: исторический опыт России $\mathrm{XX}$ века: сборник материалов всероссийской научной конференции. Челябинск, 28-29 ноября 2009 г. Челябинск. 2009. С. 253-266.

${ }^{15}$ См. Маркевич А.М., Соколов А.К. «Магнитка близ Садового кольца»: Стимулы к работе на Московском заводе «Серп и молот», 1883 - 2001 гг. М. 2005; Журавлёв С.В., Мухин М.Ю. «Крепость социализма»: Повседневность и мотивация труда на советском предприятии, 1928 - 1938 гг. М. 2004.

${ }^{16}$ См. Общество и власть: 1930 -е годы. Повествование в документах. М. 1998; Голос народа: Письма и отклики рядовых советских граждан о событиях 1918-1932 гг. М. 1998.
} 
дустриального рывка 1930-х гг. на основе архивных фондов двух заводов московского региона. Важно отметить, что оценить эффективность работы системы образования на промышленных предприятиях и выявить механизмы решения основных проблем невозможно без обращения к архивным материалам. Объектом исследования являются два машиностроительных предприятия: Люберецкий завод сельскохозяйственного машиностроения им. Ухтомского и Егорьевский станкостроительный завод «Комсомолец». ${ }^{17}$. Краткая характеристика данных предприятий, а также причины выбора именно этих заводов представлены в ранее опубликованной статье серии ${ }^{18}$. Важно отметить также, что первостепенное внимание в исследовании уделяется вопросам профессионального образования, которое полностью входило в компетенцию самих предприятий. Вопросы общего образования затрагиваются лишь частично, в том случае, если курсы или занятия проводились непосредственно заводом.

Рассмотрим более подробно на базе архивных документов систему функционирования образовательной сферы на Егорьевском станкостроительном заводе «Комсомолец».

Статус техникума и учебно-производственного комбината подразумевал под собой наличие на Егорьевском заводе относительно развитой системы технического образования. И действительно, используя прошлый методический опыт, завод готовил специалистов как для своих производственных нужд, так и для других предприятий, практически с момента своего возникновения (то есть с начала 1930-х гг.). Всего на заводе действовали три основные образовательные схемы: 1) ученическая сетка (когда ученики-подростки начинали осваивать производственный процесс непосредственно в цехах); 2) обучение через школу ученичества массовых профессий (ШУМП), составлявшее 6 месяцев (впрочем, этот срок, как отмечает руководство завода в годовом отчёте за 1931 г., не всегда выдерживался); 3) бригадное и индивидуальное переобучение в цехах. Затраты по ШУМПу составили за 1931 г. порядка 81,7 тыс. руб. (около 400 руб. на ученика). Завод подготовил по заказу 49 литейщиков и 101 станочника, а для собственных нужд - всего 91 рабочего: это, безусловно, свидетельствует о том, что в первые годы своего существования Егорьевский завод во многом носил ещё статус технического образовательного учреждения, работая в этой сфере зачастую в убыток ${ }^{19}$.

\footnotetext{
${ }^{17}$ ЦГАМО. Ф. 4281. Там же. Ф. 7979.

18 См. Фадеев Л.А. Ударничество и стахановское движение на предприятиях машиностроительной отрасли в годы первых пятилеток // Исторический журнал: научные исследования, 2013. 19 Там же. Ф. 7979. Оп. 1. Д. 1а. Л. 2 - 3.
}

В это время на заводе активизируется изобретательская деятельность. Так фонд содействия рабочему изобретательству за 1931 г. вырос в 316 раз (с 316 руб. до 9698 руб.), а созданный только в 1931 г. фонд технического просвещения рабочих составил 2077 руб. ${ }^{20}$.

Данные по заводским расходам на образование за 1932-33 гг. отрывочны и содержатся преимущественно в общих годовых отчётах по основной деятельности завода. Отмечается только, что в 1933 г. по направлениям дополнительного образования они составили 18 тыс. руб. (из них 9,9 тыс. руб. ушло на заработную плату преподавательского и административного состава учебных заведений) 21 .

Переломным моментом в образовательной политике завода стало отделение его образовательной части от производственной: на основании приказа № 270 Главного управления станкоинструментальной промышленности СССР от 26 ноября 1934 г. учебная часть комбината выделялась в самостоятельную административную единицу ${ }^{22}$.

В годовом отчёте за 1934 г. отмечается, что непосредственно на балансе завода в учебных заведениях (после отделения) состояло 8 сотрудников, на заработную плату, которым ушла 21 тыс. руб., не считая различных доплат (в том числе за отпуска и натуральными выдачами) ${ }^{23}$. Таким образом, очевидно, что становление завода, уменьшило объём его образовательных функций и сделало затруднительным отслеживать непосредственно по заводской документации образовательную ситуацию в бывших ученических цехах, которые теперь уже заводу не принадлежали; однако в дальнейшем с каждым годом статистика становилась всё более полной, расширялась и сеть образовательных программ в цехах завода.

Так, в частности, уже в 1936 г. образовательные функции завода приобретают достаточно чёткие очертания, имеется и более полная статистика. Персонал учебных заведений насчитывал 48 человек, ещё 26 сотрудников были заняты проведением различных курсов. Годовой фонд заработной платы составлял 108 тыс. руб. Фиксируются также данные о начислениях на заработную плату: на социальное страхование, ясли, содержание завкомов и пр. ${ }^{24}$. Теми или иными образовательными услугами на заводе оказывается охвачена почти половина всех рабочих (722 из 1624 человек) (см. табл. 1).

\footnotetext{
${ }^{20}$ Там же. Л. 83 - 85.

${ }^{21}$ Там же. Д. 4. Л. 57, 112.

${ }^{22}$ Там же. Оп. 1. Л. 1 - 5.

${ }^{23}$ Там же. Д. 7. Л. 60a, 61.

${ }^{24}$ Там же. Д. 11. Л. 22, 23.
} 
Таблииа 1

Образовательные курсы на Егорьевском заводе в 1936 г.

\begin{tabular}{|l|c|c|}
\hline Название курса & $\begin{array}{c}\text { Охват } \\
\text { (чел.) }\end{array}$ & $\begin{array}{c}\text { Сдало гостех- } \\
\text { әкзамен }\end{array}$ \\
\hline Техникум & 302 & 133 \\
\hline Стахановские курсы & 124 & - \\
\hline $\begin{array}{l}\text { Курсы мастеров социалисти- } \\
\text { ческого труда }\end{array}$ & 179 & - \\
\hline Курсы шоферов & 35 & - \\
\hline Немецкий язык & 34 & 25 \\
\hline $\begin{array}{l}\text { Курсы повышения квалифика- } \\
\text { ции электриков }\end{array}$ & 2 & - \\
\hline Русский язык для иностранцев & 10 & - \\
\hline Заочное отделение & 36 & - \\
\hline ИТОГО & 722 & 158 \\
\hline
\end{tabular}

Источник: ЦГАМО. Ф. 7979. ОП. 1. Д. 11. Л. 79

Данные таблицы позволяют сделать два ключевых вывода: 1) несмотря на отделение от завода учебной части, руководство, преодолев временные организационные трудности, продолжало контролировать образовательную политику; только теперь учёт вёлся в отношении непосредственно рабочих завода, и не могло возникнуть, например, ситуации (как это часто было раныше), когда завод на свои средства готовил кадры для других предприятий; 2) наиболее важным в образовательном плане был техникум, который оказывал более $40 \%$ всех образовательных услуг.
Архивные материалы предприятия позволяют прийти к выводу о том, что заводскому образованию в середине 1930-х гг. уделялось повышенное внимание. Это представляется вполне закономерным в рамках государственной политики того времени, и, в частности, на Егорьевском заводе в количественном выражении была охвачена различными профессиональными (преимущественно техническими) курсами значительная часть кадрового состава.

В 1937 г. предприятие также поддерживало высокий образовательный статус. Количество учеников в среднем было относительно велико и находилось приблизительно на уровне трети от производственных рабочих и пятой части всего персонала завода. На предприятии в это время функционировали школы ФЗУ, ДЗУ, курсы мастеров социалистического труда, стахановские курсы. Работал и техникум, как с отрывом, так и без отрыва от производства. Вызывают интерес сведения о заработной плате административного и педагогического состава учебных заведений, которые позволяют составить представление о приоритетах и структуре расходов завода на образование (см. табл. 2).

Как видно из таблицы: главные образовательные функции несли на себе школы ФЗУ и техникум без отрыва от производства. Стахановское движение было достаточно слабым в образовательном плане, очевидно, что стахановский опыт в рамках курсов передавался медленно и лишь небольшому числу учеников. Данные по техникуму с отрывом от производства, возможно, не полны (так как про-

Таблича 2

Затраты на образовательную систему Егорьевского завода и число обучающихся в 1937 г.

\begin{tabular}{|c|c|c|c|c|c|c|c|c|}
\hline & \multicolumn{3}{|c|}{$\begin{array}{c}\text { Заработная плата персонала } \\
\text { тыс. руб. в } 2 .\end{array}$} & \multirow[b]{2}{*}{$\begin{array}{c}\text { Каниелярские } \\
\text { и хозяйственные } \\
\text { расходы }\end{array}$} & \multirow[b]{2}{*}{$\begin{array}{l}\text { Прочие } \\
\text { расходы }\end{array}$} & \multirow[b]{2}{*}{$\begin{array}{c}\text { Всего } \\
\text { расходов }\end{array}$} & \multirow[b]{2}{*}{$\begin{array}{l}\text { Число } \\
\text { групn }\end{array}$} & \multirow[b]{2}{*}{$\begin{array}{l}\text { Число обу } \\
\text { чаютихся }\end{array}$} \\
\hline & $\begin{array}{l}\text { Админи- } \\
\text { страчия }\end{array}$ & $\underset{\text { поги }}{\text { Педа- }}$ & $\begin{array}{l}\text { Инструк- } \\
\text { тора }\end{array}$ & & & & & \\
\hline Школы ФЗУ & 53 & 13 & 43 & 15 & 13 & 137 & 4 & 127 \\
\hline Школы ДЗУ & - & 3 & - & 5 & 2 & 10 & 1 & 12 \\
\hline $\begin{array}{l}\text { Школы мастеров социалисти- } \\
\text { ческого труда }\end{array}$ & 12 & 21 & - & 2 & 1 & 36 & 6 & 68 \\
\hline Стахановские курсы & - & 2 & - & - & - & 2 & 3 & 25 \\
\hline $\begin{array}{l}\text { Техникум с отрывом от про- } \\
\text { изводства }\end{array}$ & - & - & - & - & 5 & 5 & 1 & 10 \\
\hline $\begin{array}{l}\text { Техникум без отрыва от про- } \\
\text { изводства }\end{array}$ & - & 8 & 1 & - & - & 9 & 9 & 80 \\
\hline ИТОГО & 65 & 47 & 44 & 22 & 21 & 199 & 23 & 312 \\
\hline
\end{tabular}

Источник: ЦГАМО. Ф. 7979. Оп. 1. Д. 14. Л. 27. 
слеживаются в отчётах весьма отрывочно), хотя и число обучающихся в нём незначительно. Большая часть средств тратилась на административнохозяйственные нужды, следом за которыми шли затраты на оплату труда педагогических кадров. Преимущественное внимание уделялось обеспечению школ ФЗУ. Самым же экономичным и, вместе с тем, широким образовательным направлением был техникум, где обучение проводилось без отрыва от производства: на 80 человек за 1937 г. завод потратил всего 9 тыс. руб. ${ }^{25}$.

Интересным представляется также сравнение с плановыми показателями, которые не выполнялись в принципе. Так, число обучающихся в 1937 г. должно было составить 611 человек, на самом же деле, учеников было всего 312. Ещё больший разрыв можно проследить по отдельным категориям. Так, например, число обучающихся в техникуме без отрыва от производства по плановым показателям должно было равняться 180, реально же училось в 2,25 раза меньше ${ }^{26}$.

Важно отметить также, что в это время завод, частично с главными комитетом и управлением учебными заведениями финансировал подготовку кадров (в т.ч. педагогических) отдельной статьёй в 217 тыс. руб. за 1937 г., ещё 14 тыс. руб. шло на техническую пропаганду. Средства инвестировались также и в научно-исследовательскую работу 50 тыс. руб. за отчётный год 27 .

В 1940 г. персонал учебных заведений состоял из 60 сотрудников с общим фондом заработной платы в 174 тыс. руб. К этому времени окончательно проясняется и позиция завода в отношении своих учеников. Так, в годовом отчёте за 1940 г. говорится о необходимости привлечения выпускников школ ФЗУ и переобученцев на производство как главного источника кадров. Важно заметить, что завод готовил меньше специалистов, чем в начале 1930-х гг., когда функционировал в качестве учебного заведения и работал во многом на заказ. Так, за 1940 г. было подготовлено 15 токарей и 8 расточников, ещё 290 человек относились в это время к категории переобученцев (доля женщин была относительно невелика и составляла около $8 \%$ ). В это время руководство завода активно апеллировало к тому факту, что в Егорьевске преобладает текстильная промышленность, на что списывались многие недочёты образовательной политики. Однако, не вызывает сомнений тот факт, что к началу 1940-х гг. Егорьевский завод окончательно утратил образовательный статус бывшего техни-

\footnotetext{
${ }^{25}$ ЦГАМО. Ф. 7979. Д. 14. Л. 27.

${ }^{26}$ Там же.

${ }^{27}$ Там же. Л. 27 - 29.
}

кума и готовил относительно небольшое число специалистов для собственных нужд, хотя количество учеников, направляемых заводом в другие учебные заведения (о чём более подробно будет сказано ниже), смягчало ситуацию нехватки квалифицированных кадров 28 .

Важным источником информации являются и данные промфинплана завода на 1940 г. Наибольший интерес представляют сведения о расходах на производственную практику. Большая часть студентов направлялась в Московский станкостроительный институт (40 человек), ещё 24 проходили обучение дома в Егорьевском техникуме «Комсомолец», по 10 студентов было направлено в Московский машиностроительный институт им. Баумана и в Белорусский политехнический институт, по 5 человек обучались в Грузинском индустриальном институте и Киевском индустриальном институте. Как видно из вышеприведённых данных, география обучения была достаточно широкой, а домашнее Егорьевское образование, хотя и ценилось, было привлекательным в плане экономии, но всё-таки уступало учёбе в столице и других крупных городах. Руководителями производственной практики назначались, как правило, ИТР, к каждому из которых прикреплялось по два студента. Оплата осуществлялась по совместительству в размере $15 \%$ от основного оклада ИТР. Студенты практиковались в течение всего года, но пик числа обучающихся, как правило, приходился на май-июнь ${ }^{29}$.

Достаточно активно на заводе функционировала система рационализаторства. Так, к концу 1940 г. насчитывалось 185 рационализаторов, что составляло около $10 \%$ от всего числа кадров и порядка $20 \%$ непосредственно от числа рабочих. Важно отметить, что число рационализаторов быстро росло. Так, только за 1940 г. их численность увеличилась на 50 человек ${ }^{30}$.

Эвакуация 1941-го г. чрезвычайно негативно сказалась на образовательной сфере завода. Количество учеников только за 1941 г. сократилось почти в два раза и превратилось в фактически неоплачиваемую трудовую неквалифицированную силу (за год фонд зарплаты учеников сократился с 3457 тыс. руб. до 443 тыс. руб.). На учебных курсах было задействовано только 4 преподавателя, фонд заработной платы которых, составлявший на тот момент 23 тыс. руб., заметно отставал от плановых 33 тыс. Заводоуправлению удалось сохранить в достаточном объёме лишь курсы массовой квалифи-

\footnotetext{
${ }^{28}$ Там же. Д. 25. Л. 21, 71

${ }^{29}$ Там же. Д. 20. Л. 95.

${ }^{30}$ Там же. Д. 25. Л. 98.
} 
кации и ряд занятий в техникуме, однако важно учесть, что статистика годового отчёта за 1941 г., где содержится данная информация, частично складывалась, в том числе, и из данных довоенного начала года (см. табл. 3).

Таблииа 3

Образовательная сфера

Егорьевского завода в 1941 г.

\begin{tabular}{|l|c|c|c|c|}
\hline & $\begin{array}{c}\text { Техникум } \\
\text { (кроме } \\
\text { техпро- } \\
\text { паганды) }\end{array}$ & $\begin{array}{c}\text { Курсы } \\
\text { массовой } \\
\text { квалифи- } \\
\text { каиии }\end{array}$ & $\begin{array}{c}\text { курсы сред- } \\
\text { ней и выс- } \\
\text { шей квали- } \\
\text { фикаиии }\end{array}$ & Итого \\
\hline Число групп & 7 & 17 & 1 & 25 \\
\hline $\begin{array}{l}\text { Число педа- } \\
\text { гогических } \\
\text { часов }\end{array}$ & 517 & 4922 & 116 & 5555 \\
\hline $\begin{array}{l}\text { Фонд зара- } \\
\text { ботной пла- } \\
\text { ты, тыс. руб. }\end{array}$ & 2 & 15,9 & 0,6 & 18,5 \\
\hline
\end{tabular}

Источник: ЦГАМО. Ф. 7979. ОП. 1. Д. 32. Л. 50.

В 1942 г. завод, несмотря на сложности военного времени, продолжал уделять внимание образованию. Из 194 учеников в середине года 60 было прикреплено к квалифицированным мастерам, ещё 74 проходили теоретическое обучение (было создано три группы токарей и одна - слесарей, обучавшихся по специальной 25 ч. программе с прохождением производственного обучения). Однако требовалась доукомплектация штата преподавателей из числа ИТР, руководство завода стремилось обязать последних нести ответственность за подготовку новых рабочих кадров ${ }^{31}$.

Таким образом, эволюция образовательной инфраструктуры на Егорьевском заводе в годы первых пятилеток представляла собой весьма своеобразный процесс, обусловленный спецификой предприятия. На пути расширения производственных программ, Егорьевский завод постепенно утрачивал образовательный статус бывшего техникума, что, с одной стороны, приводило к сокращению реальных образовательных программ, а с другой способствовало превращению бывшего техникума в станкостроительное предприятие. Переломным моментом стал 1934 г., когда учебная часть комбината выделилась в самостоятельную административную единицу. С этого времени начинается развитие образовательной сферы самого завода. Теперь предприятие готовило кадры только для собственных нужд и наращивало образовательный потенциал вплоть до начала Великой Отечествен-

${ }^{31}$ ЦГАМО. Ф. 7979. Д. 37. Л. 42. ной войны, но даже и в тяжёлые военные годы Егорьевский завод смог сохранить образовательные традиции, заложенные ещё во время его функционирования в качестве техникума. Однако, на протяжении первых пятилеток планы по образованию, тем не менее, не выполнялись: так, например, по данным 1937 г. число обучающихся отставало от запланированных цифр более чем в 2 раза.

На Люберецком заводе развитие образовательной сферы существенно отличалось от ситуации на Егорьевском предприятии. Прежде всего, это было связано с масштабами производства. Несмотря на отсутствие учебных традиций, которые существовали на Егорьевском заводе, предприятие им. Ухтомского имело значительно больший материальный потенциал, поэтому система образования носила заметно более разветвлённый и многоплановый характер, что вызывало, однако, свои сложности. Обратимся к архивным данным, представленным в фонде Люберецкого завода ${ }^{32}$.

Согласно плану организации обучения рабочих массовых профессий от 1931 г. на 10-е мая 1931 г. в фабрично-заводских училищах обучалось 306 учеников (из них 230 будущих слесарей, 52 токаря, 8 фрезеровщиков и 16 строгальщиков - все до 5-го разряда). Главными проблемами в работе ФЗУ были отсутствие (и задержка строительства) учебного помещения, а также «несоответствие потребностей» (другими словами, в ФЗУ ощущалась острая нехватка станочного оборудования) ${ }^{33}$.

Наряду с ФЗУ функционировали и школы ученичества массовых профессий, которые вполне соответствовали своему названию, так как там по данным 1931 г. обучалось 568 учеников. Важную роль играла также и вечерняя школа, обучавшая 310 человек на слесарей, токарей и фрезеровщиков. Проблемы здесь были аналогичны сложностям, сопутствующим работе ФЗУ - не хватало помещений. Помимо всего прочего, отмечалось также, что не была налажена работа в механически-сборочных цехах и 48-м отделе, требовалось увеличить число бригад с квалифицированными инструкторами ${ }^{34}$.

На заводе имелись также и другие формы образования, уже относительно малочисленные. Так, различные краткосрочные курсы (как групповые, так и индивидуальные) посещали 229 человек (как правило, это были рядовые браковщики, формовщики и монтёры); вновь поступившие учились от 3 до 30 дней. Младший административно-технический персонал проходил специальные фабрично-заводские технические курсы (65 человек), ещё 50 об-

\footnotetext{
${ }^{32}$ Там же. Ф. 4281.

${ }^{33}$ Там же. Оп. 2. Д. 41. Л. 1 - 27.

34 Там же.
} 
учалось в вечернем техникуме, отдельно занятия посещали 22 женщины. Курсы начальников цехов посещали 25 человек. Ещё 75 стажировались в Москве, в том числе 40 заочно. Относительно эффективно функционировали кружки ликбеза (ликвидации безграмотности) - к концу 1931 г. на заводе осталось всего около 50 неграмотных сотрудников и 640 малограмотных. Ещё 87 человек готовились к поступлению в ВУЗы, из них 41 специально в институт им. Калинина. На заводе функционировала также и система общего образования, охватывавшая 835 человек, и общеобразовательные курсы (без целевой установки), которые посещались ещё 57 учениками ${ }^{35}$.

Таким образом, в процесс длительной учёбы было вовлечено 2535 человек (из них 1661 взрослый), то есть 25-26\% от всего числа рабочих завода, что свидетельствовало о существенном внимании руководства завода к квалификации и грамотности своих кадров ${ }^{36}$.

Важно отметить также, что согласно протоколу № 29 заседания правления Союзсельмаша от 24.05.1931. было решено довести набор учеников в ФЗУ и ШУМПы до 7000 человек за ближайшие несколько лет. Предпочтение отдавалось детям колхозников и рабочих, планировалось набрать $50 \%$ девушек. Люберецкий завод как передовик в своей области активно следовал данному протоколу: так, только за июль 1931 г. на обучение было взято 90 человек, а, например, в сентябре уже 210. На расширение ФЗУ руководство завода в 1931 г. направило 250 тыс. руб. Всего же с учётом средств правления и перераспределения ресурсов лимит средств на образование доходил почти до 3 млн. руб. в год ${ }^{37}$.

Характеризуя педагогический состав, отметим, что в статистических данных завода сохранились сведения о месячных ставках преподавателей. Самыми высокооплачиваемыми были профессора индустриальных и сельскохозяйственных вузов (700 рублей в месяц при 440 часах в год), за ними шли доценты (500 рублей) и профессора художественных и музыкальных учебных заведений (300 рублей), по 250 рублей зарабатывали старшие преподаватели физкультуры и военных дисциплин, 210 - преподаватели музыки и иностранных языков. Самыми низкооплачиваемыми были работники ШУМПов, школ, техникума и рабфаков от 85 до 150 рублей в месяц. В целом, данные сведения вполне чётко иллюстрируют основные образовательные акценты, а именно - доминирование технического образования высокого уровня ${ }^{38}$.

\footnotetext{
${ }^{35}$ ЦГАМО. Ф. 4281. ОП. 2. Д. 41. Л. 1 - 27.

${ }^{36}$ Там же.

${ }^{37}$ Там же. Д. 18. Л. 21, 37, 85.

${ }^{38}$ Там же. Д. 41. Л. 20 - 27.
}

Таким образом, можно отметить, что в начале 1930-х гг., несмотря на ряд производственных сложностей, связанных с выполнением первого пятилетнего плана, образовательная и воспитательная системы завода, имевшие в перспективе большое значение для будущего роста предприятия, развивались достаточно активно. Главными же проблемами были нехватка оборудования и помещений для занятий.

К середине 1930-х гг. заметно улучшается производственно-бытовая инфраструктура образовательной системы. Так, например, в 1935 г. в мастерских ФЗУ был оборудован второй запасной выход (12 тыс. руб.), усовершенствована система отопления (18,2 тыс. руб.), построен специальный подъёмник (20 тыс. руб.) ${ }^{39}$. В 1935 г. были созданы также первые проекты построения дома техники, как «педагогически заострённого инструмента». Отдельно ставился вопрос экспонирования - планировалось установить 50 стендов с 200 створками на общую сумму в 40 тыс. руб. ${ }^{40}$.

Динамику контингента учащихся в 1934-35 гг. характеризует следующая таблица (см. табл. 4).

Таблииа 4

Динамика контингента учащихся
на Люберецком заводе в 1934-35 гг.

\begin{tabular}{|l|c|c|c|}
\hline Формы обучения & $\begin{array}{c}\text { Обучавшихся } \\
\text { в 1934 г. }\end{array}$ & $\begin{array}{c}\text { Выпуск } \\
\text { 1934 г. }\end{array}$ & $\begin{array}{c}\text { Обучавшихся } \\
\text { в 1935 г. }\end{array}$ \\
\hline ФЗУ, 6 месяцев & 393 & 329 & 184 \\
\hline ФЗУ, 12 месяцев & 159 & 36 & 230 \\
\hline ДЗУ & - & - & 35 \\
\hline $\begin{array}{l}\text { Производственно- } \\
\text { технические курсы }\end{array}$ & 473 & 166 & 607 \\
\hline $\begin{array}{l}\text { Коммунистическое } \\
\text { среднее образо- } \\
\text { вание }\end{array}$ & 40 & - & 120 \\
\hline Заочное обучение & 25 & - & 50 \\
\hline $\begin{array}{l}\text { Дополнительное } \\
\text { образование сред- } \\
\text { ней квалификации }\end{array}$ & 269 & - & 449 \\
\hline $\begin{array}{l}\text { Хозяйственное } \\
\text { обучение }\end{array}$ & 10 & - & 10 \\
\hline Курсы диспетчеров & - & - & 30 \\
\hline $\begin{array}{l}\text { Дополнительное } \\
\text { обучение рабочих }\end{array}$ & - & - & 115 \\
\hline $\begin{array}{l}\text { Партийная и про- } \\
\text { фсоюзная «1000» }\end{array}$ & 3 & - & 3 \\
\hline ВСЕГО & 1372 & 531 & 1833 \\
\hline
\end{tabular}

Источник: ЦГАМО. Ф. 4281. Оп. 2. Д. 185. Л. 70.

\footnotetext{
${ }^{39}$ Там же. Д. 185. Л. 13.

${ }^{40}$ Там же. Л. 33 - 37.
} 
Таким образом, как видно из таблицы, контингент учащихся с 1934 по 1935 гг. возрос более чем на треть, при этом сроки обучения, как правило, удлинялись (возросло число обучающихся в техникуме и по годовым курсам ФЗУ), при этом появлялись и новые формы образования, такие как ДЗУ (школы дозаводского ученичества), курсы диспетчеров и др.

В заводской документации имеется также более подробная информация по отдельной школе ФЗУ, которая представляет собой существенный исследовательский интерес. Речь идёт о школе, располагавшейся (по данным на 1 июля 1934 г.) на Киселёвской улице. В ней было 166 учащихся. Большая часть была детьми рабочих (76 человек), затем шли дети колхозников (55 человек), в школе также обучалось 25 детей крестьян-единоличников, восемь детей служащих, один - кустаря и один детдомовец. Большая часть посещала шестимесячные курсы - 98 человек, остальные обучались год. На базе семилетнего образования в школу ФЗУ пришло 34 ученика, шестилетнего - 69, пятилетнего - 63. В мае-июне из школы было отчислено пять человек (четыре за прогулы и один за неуспеваемость): все дети колхозников ${ }^{41}$. Преподавались в школе как производственные, так и теоретические дисциплины (специальное дело, материаловедение, чтение чертежей). Разброс оценок по всем предметам выглядел следующим образом: преобладали тройки (264), четвёрок было вдвое меньше (131), а пятёрок и вовсе очень мало (21). Занятия по политучёбе велись отдельно в специально созданных семи группах ${ }^{42} .67$ учащихся посещали библиотеку, по данным которой в среднем в месяц читалось 78 книг. 100 обучающихся получали $50 \%$ скидку на обед в школьном буфете. 60 учащихся проживало в общежитиях, где периодически проводились массовые игры, научные беседы, викторины, а также шахматно-шашечные сыгровки. Смена белья осуществлялась 3 раза в месяц. Многие из учащихся летом направлялись на отдых. Всего на 1934 г. завод предоставил ученикам 120 путёвок (из них 88 в дома отдыха, 25 в санатории) ${ }^{43}$. При этом путёвки давались преимущественно в местные организации: все попытки руководства получить направления на юг заканчивались неудачно, так как Главсельмаш регулярно ссылался на отсутствие путёвок в Сочи и на другие морские курорты ${ }^{44}$.

С 1934 г. возрастает необходимость в специалистах по транспорту. Так, согласно приказу НКТП

\footnotetext{
${ }^{41}$ ЦГАМО. Ф. 4281. Оп. 2. Д. 128. Л. 144.

42 Там же. Л. 145.

43 Там же. Л. 146.

44 Там же. Л. 147.
}

№ 1252 от 25 сентября 1934 г. (индекс 225) «О подготовке кадров для автотранспорта» в государственных масштабах по отрасли необходимо было готовить 50000 специалистов в год. Люберецкий завод активно включился в работу по подготовке диспетчеров (см. табл. выше), однако курсы шоферов и автомехаников отдельно открыты не были ${ }^{45}$.

С марта 1936 г. большое внимание стало уделяться различным курсам стахановцев. Под председательством начальника отдела кадров Борисова было проведено совещание ответственных руководителей по техникуму и курсам стахановцев, на котором активно обсуждались вопросы прохождения учёбы в техникуме и комплектования групп стахановцев ${ }^{46}$. Вопросы решались достаточно оперативно. Так, например, было решено собрать отдельное методическое совещание преподавателей, что было сделано уже через несколько часов. Помимо всего прочего было решено развернуть социалистическое соревнование между преподавателями кружков техучёбы, повысить уровень воспитательной работы (исключить курение и разговоры на занятиях) и провести разъяснительную работу среди рабочих для повышения уровня посещаемости занятий. Среди главных проблем была отмечена слабость работы по комплектации курсов стахановцев ${ }^{47}$.

На методическом совещании преподавателей 29 марта 1936 г. был заслушан доклад инженера-методиста Стоянова о работе преподавателей по новым программам, методике преподавания и увязке преподавания арифметики, физики, химии и чтения чертежей. В итоге было принято методическое письмо № 1 отдела кадров о преподавании элементов общеобразовательных предметов на курсах технического минимума и стахановских курсах. Помимо данного решения был поднят и ряд других наиболее остро стоявших вопросов, достаточно полно характеризующих основные проблемы образования на заводе в целом. В частности, было решено: 1) организовать персональную выдачу учебных пособий из цеховой библиотеки-передвижки, урегулировать вопросы подачи списков дополнительной литературы; 2) в учёбе «применять широко наглядные пособия, машины, приспособления, механизмы и отдельные детали, а также диапозитивы, диаграммы и плакаты»; 3) усилить внимание к поддержке дисциплины - запретить курение и посторонние разговоры на занятиях, снимать верхнюю одежду и вообще «создавать вполне школьную обстановку на уроке»; 4) вести

\footnotetext{
45 Там же. Л. 107.

46 Там же. Д. 202. Л. 1.

47 Там же. Л. 2.
} 
классный журнал с достаточной тщательностью; 5) следить за посещаемостью и подавать сводку ответственному по технической учёбе, делать устные выговоры прогульщикам; 6) вести контроль конспектов, устроить конкурс на лучший конспект и лучшую группу; 7) организовать консультационные столы для разъяснительной работы; 8) оповещать рабочих в стенгазете и «теребилке» (общезаводская газета) о ходе учёбы; 9) рекомендовать преподавателям посещать специальные консультационные занятия. Как видно из вышеприведённого перечня, одной из главных проблем, связанных с образованием на заводе, была дисциплина, и даже на самом совещании присутствовали не все; так, например, в протоколе отмечено, что «представитель бюро ИТС не прибыл» ${ }^{48}$.

В конце марта 1936 г. прошло также и организационное собрание курсов мастеров социалистического труда. В докладе Давыдова (директора курсов) была дана точная характеристика режима учебного года, программы курсов и порядка занятий. Отдельно говорилось об обязанностях курсантов, поднятии общеобразовательного, политического и технического уровня стахановцев. В докладах других руководящих лиц отмечалось также, что материальная база занятий обеспечена и финансовых сложностей в этом вопросе нет. Собрание прошло достаточно активно: на нём присутствовало 52 человека, было задано 16 вопросов, преимущественно связанных с отпусками и каникулами, увязкой общественной работы с курсами, а также был поднят вопрос о социальной базе курсов. В целом же, упор делался на инициативу самих работников, характерна, например, фраза одного из участников совещания Дроздова: «Истинные стахановцы давно осознали потребность в учёбе» 49 .

Культивация стахановского движения поставила перед руководством завода новые задачи. Так в переписке с начальником бухгалтерии НКТП Ф. Шефером в 1936 г. отмечалось: «Развитие стахановского движения ставит перед бухгалтерами тяжёлой промышленности неотложную задачу путём улучшения постановки бухгалтерского учёта и надлежащей его организации содействовать дальнейшему развитию стахановского движения и рентабельности предприятий тяжёлой промышленности» 50 . В этих целях для повышения уровня теоретических знаний бухгалтеров были организованы специальные двухгодичные заочные курсы при Московском Инженерно-Экономическом заочном институте; в первую очередь, обучаться

\footnotetext{
${ }^{48}$ ЦГАМО. Ф. 4281. ОП. 2. Д. 202. Л. $3,4$.

${ }^{49}$ Там же. Л. 5 - 7.

${ }^{50}$ Там же. Д. 189. Л. 23.
}

на них должны были главные бухгалтера и их заместители (в случае, если у них не было законченного высшего образования) ${ }^{51}$.

Отдельной задачей руководства завода была помощь тем ученикам ФЗУ, которые являлись воспитанниками детских домов. Так, например, 6 октября 1936 г. ответственный секретарь Деткомиссии Мособлисполкома Севастьянова направила директорам ФЗУ и завода письмо с просьбой о помощи бывшим воспитанникам детского дома А. Васину и А. Фёдорову, которые после зачисления в школу ФЗУ по первому разряду ученической сетки слесарной специальности с окладом 51 руб. 34 коп. в месяц, ещё не получив первой заработной платы, нуждались в средствах на питание и в общежитии. Севастьянова указывала, что в случае затяжки решения письмо будет переадресовано Президиуму Мособлисполкома. В результате, проблема была решена оперативно, приблизительно за неделю ${ }^{52}$.

Отметим, что директор завода периодически проводил беседы со студентами, выявляя их проблемы. Так, в ходе одной из них, проведённой в 1936 г., студенты сообщили, что их заработная плата редко отличается от таковой у копировщиц с низшим образованием (250 рублей), а конструкторы с высшим получают от 200 до 225 рублей; в то же время конструкторы конструкторско-эксплуатационного отделения (КЭО) сразу после курсов получают от 275 до 300 рублей. Этим, по мнению, студентов, во многом объяснялась текучесть кадров. Отдельно учащиеся просили директора предоставить им две-три комнаты в одном бараке для совместного проживания. Всего студентов с похожими проблемами насчитывалось порядка 40 человек ${ }^{53}$. Более подробно вопросы, связанные с ключевыми проблемами в области заработной платы, в частности, с её дифференциацией у различных категорий рабочих, тарифными ставками и пр., рассматриваются в отдельной статье цикла ${ }^{54}$.

В 1937 г. штат школы ФЗУ по сравнению с предыдущим годом сократился с 22 до 19 человек; при этом фонд заработной платы вырос с 51611 руб. в 1936 г. до 55563 руб. в 1937 г. Значительно возрос уровень заработной платы у отдельных сотрудников ФЗУ, в то время как у низкоквалифицированного персонала оклады сократились (см. табл. 5).

\footnotetext{
51 Там же.

52 Там же. Л. 35 - 36.

53 Там же. Л. 153.

54 Фадеев Л.А. Заработная плата рабочих машиностроительных предприятий в годы первых пятилеток: проблемы мотивации труда // Историко-экономические исследования. Т. 12. № 3. - Иркутск, 2011. - С. 143 - 165.
} 
Таблииа 5

Месячная заработная плата работников школы ФЗУ в 1936 - 37 гг.

\begin{tabular}{|l|c|c|}
\hline Категория & $\mathbf{1 9 3 6}$ г, руб. & $\mathbf{1 9 3 7 ~ г . , ~}$ руб. \\
\hline Начальник школы & 650 & 715 \\
\hline Бухгалтер & 312 & 420 \\
\hline Библиотекарь & 150 & 200 \\
\hline $\begin{array}{l}\text { Сторожа, уборщи- } \\
\text { цы, истопники }\end{array}$ & 113 & 75 \\
\hline
\end{tabular}

Источник: ЦГАМО. Ф. 4281. Д. 214. Л. 203

Эта тенденция отражала общую установку на введение более дифференцированной системы оплаты труда в промышленности.

Сократились затраты на содержание учебнопроизводственных мастерских (с 48343 в 1936 г. до 43529 руб. в 1937 г.), шесть из которых располагались в помещениях общежитий. Педагогический состав состоял из пяти преподавателей-совместителей и 18 инструкторов. Затраты на их заработную плату составили в 1937 г. 27982 руб. (5596 руб. на каждого) и 56400 руб. (3133 руб. на каждого) соответственно, не считая надбавок и доплат за заведование кабинетами ${ }^{55}$.

В 1937 г. заработная плата учителям была повышена в 2 раза, но сохранялась задолженность. Руководство завода уделяло также внимание и ремонту школ, однако и в этом направлении возникали сложности - из 300 тыс. руб. плана реализовано было только 70 тыс. руб. ${ }^{56}$.

В целом, к завершению второй пятилетки образовательная инфраструктура на Люберецком заводе характеризовалась двумя основными тенденциями: 1) увеличение числа различных курсов и занятий; 2) снижение дисциплины, которая в некоторых случаях доходила до критической отметки. Так, в контексте первой тенденции следует отметить, что на заводе помимо набора в различные группы (например, зимний набор без отрыва производства в группы Московского энергомашиностроительного техникума или 150-часовые курсы по калибровому хозяйству с практикой в лаборатории), активно функционировала и система проведения различных специальных практик по испытанию и сборке сельскохозяйственных машин. Говоря же о снижении дисциплины, следует отметить, что ряд организованных курсов мог по различным причинам просто не посещаться или игнорироваться рабочими. Характерным являет-

\footnotetext{
${ }^{55}$ ЦГАМО. Ф. 4281. ОП. 2. Д. 214. Л. 204.

${ }^{56}$ Там же. Д. 218. Л. 21, 23.
}

ся, например, обращение ОТК к начальнику отдела № 39, в котором отмечалось, что все попытки собрать мотористов в декабре не увенчались успехом и, несмотря на ясные установки и распоряжения директора завода, они упорно не являлись на занятия ${ }^{57}$.

В 1936-37 г. на заводе были решены вопросы, связанные с отчислениями из заработной платы на образовательные нужды. Согласно приказам по НКТП № 557 от 28 марта 1936 и № 154 от 13 февраля 1937 г. отчисления на массовую подготовку кадров, работу техникума и техническую пропаганду составили $0,75 \%$ от заработной платы; $0,5 \%$ направлялось на массовую подготовку кадров и содержание техникума для рабочих, а $0,25 \%$ шло на техническую пропаганду $(0,15 \%$ - на централизованные мероприятия главного управления учебными заведениями (ГУУЗа), 0,1\% - на работу самого предприятия по техпропаганде) ${ }^{58}$.

Таким образом, к концу второй пятилетки образовательная система Люберецкого завода носила разветвлённый характер: занятия в техникуме и курсы на самом предприятии активно дополнялись обучением за пределами завода, как в рамках командировок в вузы, так и в виде отдельных практик. Материальная база образовательной инфраструктуры также постоянно совершенствовалась. Главной же проблемой стали мотивационные аспекты заводского образования: слабой была дисциплина, рабочие нередко пропускали занятия, аргументируя это отсутствием достаточной увязки заработной платы и других благ с уровнем образования.

Профессиональное образование на промышленных предприятиях в годы первых пятилеток являлось одним из ключевых факторов индустриализации. Освоение новых технологий, поднятие культурного уровня рабочих, их политической грамотности осознавались государством и руководством предприятий как базисные элементы формирования нового социалистического общества. Анализ опыта отдельных предприятий машиностроительной отрасли, а именно - Люберецкого завода сельскохозяйственного машиностроения и Егорьевского Станкостроительного завода позволил выявить особенности и общие черты механизма реализации общесоюзных решений в рамках отдельных предприятий. На обоих заводах повышенное внимание уделялось техническим дисциплинам и политической работе среди учащихся. В то же время Люберецкий завод, как более масштабный, имел значительно более разветвлённую образовательную инфраструктуру; существенное внимание

\footnotetext{
${ }^{57}$ Там же. Д. 232. Л. 3 - 12.

${ }^{58}$ Там же. Д. 209. Л. 24.
} 


\section{Исторический журнал: научные исследования № 3 (15) • 2013}

уделялось, в том числе, и общему образованию, а также высшему, причём в ведущих технических вузах страны. И если в первой половине 1930-х гг. Егорьевский завод, сохраняя импульс от традиций своего исходного статуса образовательного учреждения, ещё представлял собой относительно замкнутую и ограниченную в себе образовательную систему, то в годы второй пятилетки руководство завода, пусть и в меньших масштабах, но также пошло по пути выхода за рамки предприятия и города, направляя своих учеников и работников в образовательные учреждения государственного масштаба. Тем не менее, меньшие размеры Егорьевского завода давали ему и некоторые преимущества: так, в частности, менее остро, чем на Люберецком заводе, стояла проблема вовлечения собственных специалистов в производство, корреляции уровня образования и заработной платы. Учитывая тот факт, что Егорьевский завод был образован на базе техникума, не так заметно ощущалась и проблема нехватки оборудования и помещений для занятий, которая была одной из ключевых на Люберецком заводе вплоть до середины 1930-х гг.

Таким образом, можно отметить, что в процессе реализации государственных задач по ликвидации неграмотности, политическому и техническому просвещению рабочих, важная роль отводилась предприятиям, и только анализируя ситуацию на конкретных заводах и проводя сравнительный анализ, можно сделать аргументированные выводы о структуре и эффективности образовательной системы в годы первых пятилеток.

\section{Список литературы:}

1. Богданов И.М. Грамотность и образование в дореволюционной России и в СССР. - М., 1964. - 206 с.

2. Диденко Д.В. Социально-экономические аспекты модернизации советской образовательной системы в условиях догоняющего развития // Мобилизационная модель экономики: исторический опыт России XX века: сборник материалов всероссийской научной конференции. Челябинск, 28-29 ноября 2009 г. Челябинск. 2009. С. 253-266

3. Журавлёв С.В., Мухин М.Ю. «Крепость социализма»: Повседневность и мотивация труда на советском предприятии, 1928 - 1938 гг. - М.: «Российская политическая энциклопедия» (РОССПЭН), 2004. - 240 с., илл.

4. Куманев В.А. Революция и просвещение масс. - М.: Наука, 1973. - 335 с.

5. Лельчук В.С. Индустриализация СССР: история, опыт, проблемы. - М.: Политиздат, 1984. - 304 с.

6. Маркевич А.М., Соколов А.К. «Магнитка близ Садового кольца»: Стимулы к работе на Московском заводе «Серп и молот», 1883 - 2001 гг. - М.: «Российская политическая энциклопедия» (РОССПЭН), 2005. - 368 с., илл.

7. Миронов. Б.Н. Экономический рост и образование в России и СССР в 19-20 веках // Отечественная история. 1994. № 4-5. C. $111-125$

8. Постановление ВЦИК СНК РСФСР от 31 августа 1925 г. «0 введении в РСФСР всеобщего начального обучения и построения школьной сети» // URL: http://www.libussr.ru/doc_ussr/ussr_2624.htm (дата обращения 19.09.12)

9. Постановление ЦИК и СНК СССР от 23 июля 1930 г. «0 реорганизации вузов, техникумов и рабфаков». URL: http://www. libussr.ru/doc_ussr/ussr_3657.htm (дата обращения 23.09.12)

10. Постановление ЦИК СССР № 11 и СНК СССР № 504 от 13 июля 1931 г. «0 порядке обеспечения стипендиями учащихся рабочих факультетов» // http://www.libussr.ru/doc_ussr/ussr_3747.htm (дата обращения: 23.09.12)

11. Постановление СНК СССР от 10 февраля 1933 г. № 181 «0 порядке стипендиального обеспечения учащихся вузов, втузов, техникумов и рабфаков» // URL: http://www.libussr.ru/doc_ussr/ussr_3860.htm (дата обращения 23.09.12)

12. Российская педагогическая энциклопедия в двух томах / Глав. Ред. В.В. Давыдов. Т.1. - М.: Большая Российская энциклопедия, 1993. URL: http://museum.edu.ru/catalog.asp?cat_ob_no=13047\&ob_no=13401 (дата обращения: 19.09.12).

13. Фадеев Л.А. Ударничество и стахановское движение на предприятиях машиностроительной отрасли в годы первых пятилеток // Исторический журнал: научные исследования, 2013.

14. Фадеев Л.А. Заработная плата рабочих машиностроительных предприятий в годы первых пятилеток: проблемы мотивации труда // Историко-экономические исследования. Т. 12. № 3. - Иркутск, 2011. - С. 143 - 165.

15. Фрид Л.С. Очерки по истории развития политико-просветительной работы в РСФСР (1917-1929). - Л., 1941. - 184 с.

16. Штамм С.И. Управление народным образованием в СССР. (1917-1936). - М.: Наука, 1985. - 282 с.

\section{References (transliteration):}

1. Bogdanov I.M. Gramotnost' i obrazovanie v dorevolyutsionnoy Rossii i v SSSR. - M., 1964. - 206 s.

2. Didenko D.V. Sotsial'no-ekonomicheskie aspekty modernizatsii sovetskoy obrazovatel'noy sistemy v usloviyakh dogonyayushchego razvitiya // Mobilizatsionnaya model' ekonomiki: istoricheskiy opyt Rossii KhKh veka: sbornik materialov vserossiyskoy nauchnoy konferentsii. Chelyabinsk, 28-29 noyabrya 2009 g. Chelyabinsk. 2009. S. 253-266 
3. Zhuravlev S.V., Mukhin M.Yu. «Krepost' sotsializma»: Povsednevnost' i motivatsiya truda na sovetskom predpriyatii, 1928 1938 gg. - M.: «Rossiyskaya politicheskaya entsiklopediya» (ROSSPEN), 2004. - 240 s., ill.

4. Kumanev V.A. Revolyutsiya i prosveshchenie mass. - M.: Nauka, 1973. - 335 s.

5. Lel'chuk V.S. Industrializatsiya SSSR: istoriya, opyt, problemy. - M.: Politizdat, 1984. - 304 s.

6. Markevich A.M., Sokolov A.K. «Magnitka bliz Sadovogo kol'tsa»: Stimuly k rabote na Moskovskom zavode «Serp i molot», 1883 2001 gg. - M.: «Rossiyskaya politicheskaya entsiklopediya» (ROSSPEN), 2005. - 368 s., ill.

7. Mironov. B.N. Ekonomicheskiy rost i obrazovanie v Rossii i SSSR v 19-20 vekakh // Otechestvennaya istoriya. 1994. № 4-5. S. $111-125$

8. Postanovlenie VTsIK SNK RSFSR ot 31 avgusta $1925 \mathrm{~g}$. «0 vvedenii v RSFSR vseobshchego nachal'nogo obucheniya i postroeniya shkol'noy seti» // URL: http://www.libussr.ru/doc_ussr/ussr_2624.htm (data obrashcheniya 19.09.12)

9. Postanovlenie TsIK i SNK SSSR ot 23 iyulya 1930 g. «0 reorganizatsii vuzov, tekhnikumov i rabfakov». URL: http://www.libussr. ru/doc_ussr/ussr_3657.htm (data obrashcheniya 23.09.12)

10. Postanovlenie TsIK SSSR № 11 i SNK SSSR № 504 ot 13 iyulya 1931 g. «0 poryadke obespecheniya stipendiyami uchashchikhsya rabochikh fakul'tetov» // http://www.libussr.ru/doc_ussr/ussr_3747.htm (data obrashcheniya: 23.09.12)

11. Postanovlenie SNK SSSR ot 10 fevralya 1933 g. № 181 «0 poryadke stipendial'nogo obespecheniya uchashchikhsya vuzov, vtuzov, tekhnikumov i rabfakov» // URL: http://www.libussr.ru/doc_ussr/ussr_3860.htm (data obrashcheniya 23.09.12)

12. Rossiyskaya pedagogicheskaya entsiklopediya v dvukh tomakh / Glav. Red. V.V. Davydov. T.1. - M.: Bol'shaya Rossiyskaya entsiklopediya, 1993. URL: http://museum.edu.ru/catalog.asp?cat_ob_no=13047\&ob_no=13401 (data obrashcheniya: 19.09.12).

13. Fadeev L.A. Udarnichestvo i stakhanovskoe dvizhenie na predpriyatiyakh mashinostroitel'noy otrasli v gody pervykh pyatiletok // Istoricheskiy zhurnal: nauchnye issledovaniya, 2013.

14. Fadeev L.A. Zarabotnaya plata rabochikh mashinostroitel'nykh predpriyatiy v gody pervykh pyatiletok: problemy motivatsii truda // Istoriko-ekonomicheskie issledovaniya. T. 12. № 3. - Irkutsk, 2011. - S. 143 - 165.

15. Frid L.S. Ocherki po istorii razvitiya politiko-prosvetitel'noy raboty v RSFSR (1917-1929). - L., 1941. - $184 \mathrm{~s}$.

16. Shtamm S.I. Upravlenie narodnym obrazovaniem v SSSR. (1917-1936). - M.: Nauka, 1985. - 282 s. 